ISSN 2080-1653

DOI 10.24917/20801653.342.8

\author{
ŁUKASZ DAMURSKI \\ Wroclaw University of Science and Technology, Poland
}

\title{
Five guidelines for local service centres
}

\begin{abstract}
The paper is a critical literature review aiming at synthesising knowledge on shaping the service sector in urbanised areas. Starting from classical concepts of hierarchical service systems (Christaller, Lösch, Palomäki, Nowakowski) through considerations on the impact of teleinformatics on the services sector, to contemporary research on hierarchical-network spatial and functional structures (Ossowicz), the paper points to the role which can be played by local service centres in spatial planning. The five guidelines for urban planning describe crucial conditions which have to be met in order to generate a positive influence on land-use and the quality of life in urban neighbourhoods. The guidelines may be a starting point for empirical research and may play an inspiring role in local policy in urbanised areas.
\end{abstract}

Keywords: local service centre; neighbourhood; services; spatial policy

Received: 18 December 2019

Accepted: 25 April 2020

\section{Suggested citation:}

Damurski, Ł., (2020). Five guidelines for local service centres. Prace Komisji Geografii Przemysłu Polskiego Towarzystwa Geograficznego [Studies of the Industrial Geography Commission of the Polish Geographical Society], 34(2), 117-128. doi 10.24917/20801653.342.8

Acknowledgement

The article presents the results of a research project titled "The model of the local service centre as a tool for shaping the territorial cohesion of urban areas" implemented at the Faculty of Architecture of the Wrocław University of Technology in 2016-2019 from the funds of the National Science Center (project number 2015/19/B/HS4/01301).

Thank you to my colleagues, dr inż. Wawrzyniec Zipser and dr Jacek Pluta for valuable insights and discussions underlying this article.

\section{INTRODUCTION}

The article attempts to synthesise current knowledge about local service centres (LSCs) and indicate the role they have to fulfil in modern spatial management. The huge amount of data and publications on modern services causes significant interpretation 
problems. As a result, it is difficult to take specific strategic decisions, including those regarding space management. There is a clear need to recapitulate and put forward simple, unambiguous statements about local service centres so that they can be used as an effective tool in spatial management.

The work plan includes a review of selected literature, a critical analysis of their content, and a proposal of five guidelines for urban policy. Starting from the genesis and definition of local service centres by describing their role in current urban discourse and the most important challenges facing services in cities, a broad picture of changes occurring in the service sector was obtained, which was finally collected in the form of theorems ordering the current state of knowledge. Although these guidelines require confirmation in empirical research, they have a significant cognitive value in themselves: they shed new light on spatial management processes on a local scale, and thus may become a source of reflection on the directions of development of cities in Poland.

\section{THE MECHANISM OF CONCENTRATION AND HIERARCHY OF SERVICE CENTRES}

A characteristic feature of services is their concentration in specific locations. On the one hand, this concentration allows clients to meet different needs in one place, and on the other, it guarantees service providers the profitability of their business (Zipser, 1983). This phenomenon can be observed at various scales (regional, city-wide, district, housing estate). Its universality is based on two elements. The first one is the accumulation of institutional, cultural, commercial and service facilities which creates the opportunity to settle several issues 'at one time'. The other one means offering a set of unique buildings and facilities, which makes it possible to settle certain matters 'only here' (see Brzosko-Sermak, Płaziak, Trzepacz, 2017).

The concentration mechanism is also sometimes referred to as agglomeration benefits. Agglomeration, i.e. locating various activities at a short distance from each other, contributes to reducing transport costs. It thus facilitates the exchange of people, goods and ideas (cf. Glaeser, 2010) which is particularly evident in large cities, which owe their position to their accumulation of services.

The sources of the phenomenon of concentration should be sought in the principle of least effort, described by G.K. Zipfa (1949). It says that people in their actions naturally choose those paths that have the least resistance which is why services are located in places that provide the right number of clients. At the same time, clients strive to minimise necessary movements. As a result, an optimal range of services is created, in which the total profits outweigh most the total costs of the service, and the concentration stabilises at a certain point in space (Zipser, 1983).

The concentration mechanism creates a system of centres in space, showing a certain hierarchy. This hierarchy takes place on the basis of size, functions and geographical distribution. These factors are the starting point for various concepts of settlement systems both on the macro (regional) and micro (within the urban system) scale. Perhaps the best known is the theory of central places of W. Christaller (1933), according to which the centrality of goods and services offered determines the city's position in the settlement network and assigns it a market of a certain size (Parissek, 1997). Lower-level central places offer basic goods, while higher-level centres offer basic and specialised goods (a pyramid of functions). Furthermore, the extent of service coverage 
at higher-level centres is a multiple of the service range for lower-level centres (see Domański, 1993). Recipients (clients) aiming at lower-order services are willing to travel only short distances, because in this way they meet frequent, daily needs, usually characterised by relatively low prices, not requiring specialised knowledge. A little further, they will travel to medium-order services, which are used slightly less often and have a higher value. Similarly, the furthest distances usually separate customers from the highest-order services that are most specialised and used sporadically (Shearmur, 2010). A modified version of the theory of central places proposed by Lösch says that centres of the same size do not necessarily offer the same functions, and larger centres do not always have all the functions occurring in smaller settlements (Haggett, 1965).

Mauri Palomäki (1964) hierarchised the centres, taking into account the division into different types of services (administration, trade, other commercial services, public services, recreation). Based on information about the number of industries present in a given spatial unit and the number of units in which a given industry occurs, charts of ordered units and industries, from the largest to the smallest, were created. The place where the graph fluidity ('stairs') broke determined the hierarchy, including industries specific to the given levels of the system.

In turn, according to the concept of the population service system (Nowakowski, 1984), there are two main criteria for shaping the hierarchical network of services:

- the shortest possible arrival time,

- the highest possible attractiveness of the centre.

The concept adopts six levels of service centres. The first - elementary, includes facilities used daily or very often, closest to the place of residence. Level 2 includes frequently used facilities, concentrated in housing service centres. Level 3 contains facilities used periodically, the majority should be concentrated in district service centres. Level 4 includes facilities of a high standard, used sporadically, concentrated in a voivodeship capital. The last two levels include pan-voivodeship centres and those found solely in the capital of the state (Nowakowski, 1984).

As regards the distribution of the lowest level services, usually visited on foot, the principle of their maximum proximity to places of residence applies. However, this approximation is limited by the possible degree of the deconcentration, which varies for particular types of services. After all, each type has a different range of service and different situational requirements. The availability of higher-level services is conditioned by the presence of particularly convenient and well-connected places (stops, nodes).

\section{CONVERSION OF SERVICES TO VIRTUAL SPACE}

The distinctive features of the virtual environment, speed, interactivity and multimedia, determine huge changes in the way entities operate on the market as broadly understood, in communication between enterprises and the market, including clients (Mazurek, 2013). It can be said that today's cities function simultaneously in the physical and virtual world. Urban areas should, therefore, be seen as two parallel structures, one of which is hooked into the physical structure and the other associated with electronic flows. Finding the right balance between what is real and what is virtual, between a city of physical spaces and a "city of bits" (Palej, 2005) will be the greatest challenge of modern times. 
In settlement geography, especially in the analysis of the distribution of services in cities, so-called agglomeration effects are observed. They are directly related to the aforementioned concentration mechanism because they describe the benefits of locating enterprises and housing next to each other, i.e. lower transport costs, and thus easy exchange of goods, people and thoughts (Glaeser, 2010). The effect of this is the settlement hierarchy as we know it today.

The spontaneity of the ICT sector in recent decades means that lower communication costs weaken concentration mechanisms and reduce the benefits of agglomeration. At the same time, urban areas remain invariably viable despite the easier flow of goods and knowledge (Glaeser, 2010). The spatial proximity of companies, employees and clients in service centres facilitates daily functioning, exchange of knowledge, efficient delivery of goods and provision of services (McKillop, Coyle, Glaeser et al., 2009). ICTs are therefore not a substitute for direct contacts, but rather a complement to them.

The processes described here can be simplified into two terms: conversion and hybridisation of services. Conversion is when the whole service is transferred to the internet, while in the case when part of the service process is carried out online and some remain offline, we talk about hybridisation. In the first case, the service loses its spatial references entirely and can be implemented from anywhere. Hybridisation, on the other hand, allows the service to preserve certain territorial features, which is an important anchor point for the concept of local service centres. It is, therefore, worth taking a closer look at this phenomenon.

The decreasing importance of distance, universal access to information, the possibility of remote handling of many matters with the simultaneous growing need for direct contacts, constitute grounds for seeking a new, non-hierarchical system of service centres in the settlement network. Tomasz Ossowicz (2013) graphically combines two concepts of the functional and spatial structure of cities. The first one is hierarchical (with multifunctional centres of different rank in the settlement system) while the other network (where there is no main city centre, and all service centres are highly specialised, e.g. in the field of trade, entertainment or gastronomy). The result of this combination is a more realistic hierarchical-network, functional and spatial structure of the city, adapted to contemporary realities, including distinct areas, some of which are located based on a hierarchical system, and some in a free way, tailored to the needs of the neoliberal economy. An important feature of such a structure is its easy accessibility for users due to the reduction of spatial barriers and a small number of enclosed areas (Ossowicz, 2013).

\section{THE ORIGIN AND DEFINITION OF A LOCAL SERVICE CENTRE}

In the context outlined above, it is worth noting that at the core of each service centre model is always some form of residential centre. Searching for the sources of the LSC idea, we need to reach for ancient Greek polises, where the main city square combined various buildings: temples, library, stalls, arsenal etc., thus being both a meeting and exchange place (both commercial and metaphysical - exchange of thoughts). Later, in the Middle Ages, very similar functions, despite different social, religious, political and economic conditions, were performed by small, orderly and consciously designed cities with their markets surrounded by buildings, equipped with various accompanying facilities (church, market) (Ostrowski, 2001). This pattern, continued in subsequent 
eras, strengthened the set of characteristic features of the urban service centre as a public space offering a specific range of services (trade, administration, finance, religion, culture, entertainment etc.).

Only the industrial era with its rapid, mass and initially unplanned urbanisation lost the human dimension of the city. It disrupted the natural processes of the concentration of services and led to the underdevelopment of urban structures based on the vicinity of complementary functions. As a result, they lost their original role of local centre as a structural factor organising residential space. Looking for answers to the problems of this era, modernists created several theoretical concepts aimed at reversing negative trends in urban development and restoring the multi-functionality of urban settlements. A special place among them is occupied by C. Perry's Neighborhood Unit, whose goal was to create functional, self-sufficient housing (at least in the basics) and offering the desired quality of life. The size of the unit $(5,000$ to 9,000 inhabitants) and its spatial form were determined by the radius of pedestrian access to the school located in the centre in a way that access to it did not require crossing the main thoroughfares. Local stores were in the main entrances to the estate, while in the centre were offices and a public square (Perry, 1998). An important, though not the main premise for creating neighborhood units was the creation of social bonds that were to develop by frequent use of the same service facilities by people living close to each other (Czarnecki, 2001).

The subordination of the scale and method of housing development to pedestrian movement turned out to be crucial in the era of car dominance. Thanks to pedestrian access to everyday services, public spaces in housing estates create an obvious sphere of human functioning and create good psychological conditions for the processes of integration of local communities and their identification with the place of residence (see Jałowiecki, Szczepański, 2002).

The universality of the neighborhood unit concept made it a reference point for shaping later LSC models, including the idea of the modern agora promoted by F. Van Klingeren in the 1960s and 1970s. According to this approach, the centre is to be a place of social integration, enabling the exchange of knowledge and cultivating various activities and interests. The functional and spatial program of the modern agora does not have to be dedicated to a specific group of people, it should be open, flexible and allow adaptation to the current needs of users in daily, weekly, monthly and yearly cycles (Kowicki, 2004).

Finally, it is worth adding that the experience of creating a new centre from scratch in the rapidly developing cities of the $20^{\text {th }}$ century has shown that the location of the centre in a completely new area, without historical traditions, is a risky procedure and doomed to failure. In order to preserve the social functions of the centre, the most important thing is to preserve the original traditional area as the nucleus of the new centre (Wallis, 1979, after Wojnarowska, 2017).

The local service centre is, therefore, an element of the functional and spatial structure of the city that can be distinguished from its surroundings by a specific form or function. As a purposefully created and properly arranged space, conducive to human presence, it focuses on social life. It is not a vast space because it is focused on satisfying the needs of relatively few people - housing estate hybrids, a 'quarter' of streets - but saturated with many functions, by the natural principle of concentration of settlement and human activity. Therefore, an LSC can be defined as a multifunctional public space 
that can be separated from the environment, providing access to essential, everyday services, conducive to social integration and building the local identity of residents.

The local service centre as a managed space, equipped with 'urban furniture', conducive to people is, on the scale of the housing estate, an added value that stands out from the surroundings. It is not a large space in terms of area, because it focuses on satisfying the needs of a relatively small number of people - housing estate hybrids, a 'quarter' of buildings. At the same time, however, it is a space deliberately created, which is a frame for various functions, also pro-social, integrating.

\section{A LOCAL SERVICE CENTRE IN CONTEMPORARY URBAN DISCOURSE}

The question 'how many, what services and where?' is present in planning practice from the very beginning, although today it acquires a special meaning. The so-called 'urban normative' (although this term has negative historical connotations in Poland, it also reflects today's search quite well) determines the parameters of the functional and spatial structure of the city and the principles of designing buildings in accordance with the principles of environmental protection. It is about the standard of access to school, kindergarten, church, nursing home, local authority, public open spaces, shops, etc. as a guarantee of the specific value and quality of space. They are expressed in the minimum or maximum size of the building, in isochrons of pedestrian access and safety conditions of this access (cf. Staniszkis, 2005, Stowarzyszenie Architektów, 2011).

In the period of systemic transformation, as part of moving away from central planning and excessive regulation of socio-economic processes, so-called urban planning was abandoned. Local authorities not only did not expect such a layer, but they were not even able to define the objectives and guidelines of social policy in spatial planning. "A plan is being prepared as expected by the authority or investor" (Staniszkis, 2005: 12).

Works on the reform of planning law in Poland aimed at ensuring rational space management, in particular the arrangement of buildings, functional coherence of planned urban complexes and minimum binding requirements in spatial planning and investment implementation (Komisja Kodyfikacyjna, 2014) have been underway for several years.

For example, 'Urban planning standards', established by ordinance of the minister competent for construction and spatial planning, binding commune bodies, when drawing up and adopting planning acts, would specify requirements regarding social infrastructure. They would include the size of areas designated for the implementation of an elementary school, junior high school, kindergarten, primary healthcare, playground, sports facilities and public green spaces - depending on the size of the town. Moreover, they would require technical infrastructure, including minimum requirements for communication service using various means of transport (Komisja Kodyfikacyjna, 2014).

A similar approach was previously used in the draft for the "National urban planning rules for land development and management” (Rada Legislacyjna..., 2008). There, determined in tabular form, the minimum number of places in schools and kindergartens was prescribed, as well as the minimum area for primary healthcare facilities per $2,500 \mathrm{~m}^{2}$ of the total area of accommodation, broken down into multi-family, single-family and residential-service buildings. 
In addition to state institutions and professional (industry) organisations, researchers in various fields are also looking for standards and norms. Particularly noteworthy is the review of various norms by G. Dąbrowska-Milewska (2010). Although it is limited to educational services and open spaces, it can still be useful for assessing LSC facilities. This is purely statistical, however, and must be critically assessed from the point of view of the arrangement of individual buildings in space and the related real-time availability of services. That is why one of the elements of searching for service standards should be an isochron analysis for various means of transport.

Time-based standards operate with different values for different services and means of transport. After putting together different approaches, we can assume that the most typical values are 15 and 30 minute distances. They are to guarantee the optimal range for residents in everyday services (this applies to both pedestrian and bicycle, public transport and individual cars). With this assumption, we can compare the availability of services in different settlement contexts.

LSCs are of particular importance due to the shift in developed countries away from quantitative to qualitative urbanisation. This is done by revitalising existing public spaces and adapting their offer to the users' needs aimed at improving the quality of life in both cities and their surroundings (see Domaradzki, Domaradzka, 2015).

Local government policy in urban areas is increasingly tackling the problem of a shortage of local service centres, recognising the growing importance of access to services and public spaces as an indispensable element of improving the quality of life and shaping local identity. A good example is the study of conditions, and directions for the spatial development of Wrocław amended in 2018 (Studium..., 2018). In the previous version of this document (Studium..., 2010), the functional and spatial structure of the city included a hierarchical system of service centres, ranging from multifunctional city-wide to specialised city-wide, connecting the centre to district centres. Currently, Wrocław's spatial policy is leaning towards local centres. A different system of centres was introduced, taking into account the additional, lowest level of the hierarchy. According to the new 'Studium...', local centres are essential public spaces for the flourishing of small communities. By performing the functions of meeting and integration, they build local identity. As multifunctional concentrations of service, social, economic and recreational and leisure activities, they respond to the various needs of residents. They offer pedestrian amenities and access to public transport and are within a 15-minute walk from home.

The ideas presented in the Wrocław's Studium are currently used in local government practice. At the time when this text was submitted for publishing, the city was developing a pilot program of so-called 'complete estates', i.e. those where residents live well because the estates meet the basic needs of residents, have their unique character and provide access to greenery (Wrocław rozmawia, 2019). The example of Wrocław confirms the growing importance of LSCs in local government policy and indicates the validity of the research undertaken.

Finally, it should be noted that the processes described here are influenced by a broader development policy which aims at improving the quality of life in urban and suburban areas, emphasizing the role of access to services as a significant factor reducing transport intensity (see Ustawa..., 2003). The concept of so-called territorial cohesion, understood as a set of principles of harmonious and effective development of a given area (cf. Territorial Agenda..., 2011), serving the optimal distribution of functions 
important for the common good (cf. Ładysz, 2014), currently plays a leading role in the rhetoric of the EU and indirectly indicates the growing importance of LSCs in spatial development processes. This will be discussed in more detail in the following sections.

\section{BIG CHALLENGES, LOCAL SOLUTIONS}

Therefore, many phenomena observed in urban areas in recent years indicate the need to develop a network of local service centres as nodal places, bringing together the lives of local communities. This goal can be achieved by thoroughly recognising current trends in the service sector in cities and an appropriate response to them in local government policy documents. Based on the theoretical research in this work, the most important challenges facing LSCs can be summarised in the following points:

1. The weakening of concentration mechanisms as a result of the permissive spatial policy of local governments, and the dynamic development of housing devoid of coordination with other sectoral policies, leads to the decentralisation of urban functions and a dilution in the hierarchy of service centres. If we add to this the problem of the 'shrinking' of many large cities, then we can clearly see that the natural rules governing the development of settlements had been disturbed. In this situation, the future condition of an urban settlement largely depends on the effectiveness of spatial management carried out by local authorities in the field of service centres. It is the LSCs that offer access to everyday services and enable not only the utilitarian needs but also a lifestyle in a friendly, neighbourly environment. Even if one adopts an extreme scenario in which future cities will not need a hierarchical system of service centres due to the development of services implemented remotely (see remarks below), the role of LSCs in the process of shaping the quality of life seems indisputable.

2. The spread of consumer attitudes in society and the related commercialisation of urban space leads to the impoverishment of social functions in service centres. On the other hand, the visible increase in the importance of locality, 'familiarity' in the social sphere and the economy requires the formation of appropriate spatial structures. The task of the LSCs will, therefore, be to enable the implementation of various social behaviours by creating an appropriate spatial and service offer, dedicated to various groups of recipients, promoting the integration of local communities and building the identity of a place.

3. The growing importance of services provided remotely and the progressive conversion of various activities carried out so far in a traditional way to virtual space weakens the importance of service centres as places offering access to many services in one place. Therefore, on the one hand, the multidimensional management of LSCs should be supported, taking into account the online and offline channels, and on the other, public space in LSCs should be shaped in such a way that it constitutes an attractive alternative to the virtual world.

It is evident that the above list is incomplete, and that it will require constant verification and updating. The changing national economic situation, fluctuations in demand and supply, sociological and demographic factors - all these determine the functioning and development of local service centres in Polish cities. It seems that the proposed LSC model, thanks to its adaptability, can effectively respond to the above-mentioned challenges today and in the future. 


\section{FIVE GUIDELINES FOR LSC}

The LSC concept stems from the need to create local service centres as an indispensable element of modern urban policy both in its strategic sphere (i.e. the vision of the development of entire settlement units) and its operational sphere (i.e. implementation of specific changes in housing estates). The following five guidelines for LSCs refer to both of these dimensions, indicating the most important properties that LSCs should have in order to be an effective tool for spatial management.

\section{Guideline 1 .}

\section{The LSC must be accessible to everyone and well connected to the urban context}

Just as the ancient Athenian agora was located on the Panatenai Road, as medieval markets at the intersection of important routes, like the Neighborhood Unit between the main routes leading to other districts, so the LSC must be well connected with other elements of the functional and spatial structure of the city. This includes both the residential areas that it serves and the higher-level centres that meet a wider range of residents' needs.

New patterns of human mobility, including the need for movement, mean that the LSC should enable safe walking on foot in public space. Bicycles, scooters, unicycles and other devices facilitating movement in the city space, which should have their place in the LSC, become an inseparable element of the local mobility policy. However, there is no need to ensure accessibility for cars, except for emergency vehicles or well-organised parking lots located in the vicinity of the LSC.

Finally, the link between the LSC and the public transport network is key. Proper location of the stops and their connection with main pedestrian and bicycle routes contributes to the increase of the vitality of public spaces in urban estates.

\section{Guideline 2 .}

\section{The LSC must consider the history and identity of the place, it must be local}

It is difficult to create any centre from scratch - attempts to artificially generate urban concentrations, locating centres outside the current settlement system, usually fail. That is why, when creating an LSC, one must always refer to the past, to the traditions and habits of the residents, and the cultural values of the place.

Also, a distinguishing feature of the LSC from higher-order service centres should be their locality understood as matching the daily needs of users living nearby, forming a specific territorial community. The recipients of the offer of the local service centre are therefore those from the neighborhood who go there to settle basic matters, and at the same time meet with friends and establish social relations.

\section{Guideline 3.}

\section{The LSC must offer a flexible functional and spatial programme}

Change is an inherent feature of the city, which is why urban planning has always been associated with the need to adapt various spatial structures to changing economic and social conditions. This was the case in antiquity when representatives of new civilisa- 
tions adapted their settlements to their needs and this is the case today when technology increasingly determines the scope of needs implemented in space.

First of all, an LSC as a spatial concentration of various functions gives users the opportunity to handle several matters in one place. Only then will the appropriate number of users and customers necessary to ensure the economic efficiency of individual commercial and service outlets be ensured.

In addition, the central public space should be constructed in such a way as to enable the LSCs to adapt to changing situations (times of the day, days of the week, seasons - see the concept of multi-use by Kowicki, 2004). Residents (users) should be able to co-decide on how space is used at a given moment.

Finally, the LSC should have significant connections with the virtual world, should be closely related to online services and tools. Only hybrid services connecting offline and online channels have a chance to survive in such a housing estate.

\section{Guideline 4.}

\section{The LSC should strengthen local community}

Strong territorial communities are understood as those with close personal ties (family, friends), participating in broad groups (workplace, school, etc.), engaging in decision-making processes and developing key services for their members (see Borys, Rogala, 2008). The role of residents should not only be the passive use of the commercial or cultural offer available within local centers, but also active participation in its creation and development.

Creating a strong local community is based on the social understanding of the quality of life as a common matter raised in its interest, and not meeting the requirements of maximising individual consumption. Meeting this condition introduces a new, partnership and participatory type of relationship between the local authority and investors (as disposers of forces and resources) and the local community and its representatives.

\section{Guideline 5.}

\section{The LSC should improve territorial cohesion in urban areas}

Territorial cohesion is a comprehensive concept of shaping development policy, which is defined by the 'Territorial Agenda of the European Union' as a set of principles of harmonious, effective and balanced spatial development of a given area (Agenda..., 2011). An element of spatial development that is particularly conducive to territorial cohesion is services. As historical experience shows, the most effective form of service delivery is a hierarchical system of service centers offering access to a diverse range of functions at individual levels of the hierarchy. A crucial role in this system is played by the LSC which is its foundation and essential component.

However, LSCs cannot be treated as isolated entities, serving to increase the internal cohesion of a closed area (housing estate, district or commune). Single LSCs, even well equipped, do not contribute to the level of territorial cohesion - only as an element of the network, connected with other LSCs and with higher-level centres can it be an effective tool of cohesion policy. 


\section{SUMMARY}

This theoretical article is a selective and critical review of the literature on local service centres in urban areas. It is guided by the assumption that a positive relationship between urban facilities and the quality of life (well-being) of residents in neighbourhoods can be achieved through planning processes, taking into account, on the one hand, centuries-old achievements of urban planning, and on the other the current dynamics of civilisation.

Aiming at a synthesis and a recapitulation of extensive knowledge in the field of shaping services in cities, five guidelines for local service centres are proposed. These guidelines can become a starting point for empirical research, they can also play an inspiring role for local policy in urban areas.

\section{References}

Agenda Terytorialna Unii Europejskiej 2020. W kierunku sprzyjającej społecznemu włączeniu, inteligentnej i zrównoważonej Europy zróżnicowanych regionów (2011). Gödöllő.

Borys, T., Rogala, P. (red.) (2008). Jakość życia na poziomie lokalnym - ujęcie wskaźnikowe. Warszawa.

Brzosko-Sermak, A., Płaziak, M., Trzepacz, P. (2017). Przemiany funkcji handlowych i usługowych centrum dzielnicy mieszkaniowej na przykładzie Krakowa-Nowej Huty. Prace Komisji Geografii Przemysłu Polskiego Towarzystwa Geograficznego [Studies of the Industrial Geography Commission of the Polish Geographical Society], 31(2), 95-110.

Christaller, W. (1993). Die zentralen Orte in Süddeutschland, Jena: Gustav Fischer.

Czarnecki, W. (2001). Historia architektury rozwoju miast i urbanistyki. Białystok: Wyższa Szkoła Finansów i Zarządzania w Białymstoku.

Dąbrowska-Milewska, G. (2010). Standardy urbanistyczne dla terenów mieszkaniowych - wybrane zagadnienia. Architecturae et Artibus, 1, 18-21.

Domański, R. (1993). Gospodarka przestrzenna. Warszawa: PWN.

Domaradzki, K., Domaradzka, A. (2015). Wstęp. W: Studium koncepcyjne dotyczq̨ce centrów lokalnych w Warszawie. Seria Warsztaty, 5. Warszawa: Wydawnictwo OW SARP; 6-9.

Glaeser, E.L. (red.) (2010). Agglomeration Economics. Chicago: The University of Chicago Press.

Haggett, P. (1965). Locational Analysis in Human Geography. London: Butler and Tanner.

Jałowiecki, B., Szczepański, M.S. (2002). Miasto i przestrzeń w perspektywie socjologicznej. Warszawa: Wydawnictwo Naukowe Scholar.

Komisja Kodyfikacyjna Prawa Budowlanego (2014). Kodeks urbanistyczno-budowlany. Projekt, wersja podstawowa przyjęta przez Komisję w dniu 16 kwietnia 2014 r. Warszawa 2014.

Kowicki, M. (2004). Wspótczesna agora. Wybrane problemy kształtowania ośrodków usługowych dla małych społeczności lokalnych. Kraków: Politechnika Krakowska.

Ładysz, J. (2014). Spójność terytorialna Unii Europejskiej a transgraniczny rozwój zintegrowany. W: J. Potocki, J. Ładysz (red.). Gospodarka przestrzenna. Dylematy i wyzwania współczesności, Prace Naukowe Uniwersytetu Ekonomicznego we Wrocławiu, 339, 76-88.

Mazurek, G. (2013). Wirtualizacja marketingu - konceptualizacja. W: L.W. Zacher (red.) Wirtualizacja. Problemy, wyzwania, skutki. Warszawa: Wydawnictwo Poltext, 265-276.

McKillop, T., Coyle, D., Glaeser, E., Kestenbaum, J., O'Neill, J. (2009). Manchester Independent Economic Review. The Case for Agglomeration Economies. Manchester: Centre for Local Economic Strategies.

Nowakowski, M. (red.) (1984). Kształtowanie sieci usług. Warszawa: PWN.

Ossowicz, T. (2013). Hierarchical vs Network City Structure in Planning. W: J. Teixeira (red.) A Centenary of Spatial Planning in Europe. Osman: ECTP-CEU, 145-156.

Ostrowski, W. (2001). Wprowadzenie do historii budowy miast. Ludzie i środowisko. Warszawa: Oficyna Wydawnicza Politechniki Warszawskiej.

Palej, A. (2005). Poszukiwanie równowagi pomiędzy światem fizycznym a światem wirtualnym we współczesnych miastach. W: A. Drapella Harmensdorfer, K. Cebrat (red.) Aspects of 
equilibrium: architecture, urban design, planning at treshold of un decade of education for sustainable development. Studia i Materiały Wydziału Architektury Politechniki Wrocławskiej, 1, 157-163.

Palomäki, M. (1964). The Functional Centers and Areas in South Bothnia, Fennia, 88. Helsinki.

Parysek, J.J. (1997). Podstawy gospodarki lokalnej. Poznań: Wydawnictwo Naukowe Uniwersytetu Adama Mickiewicza.

Perry, C. (1998). The Neighbourhood Unit, a Scheme for Arrangement for the Family Life Community (1929). Reprinted. London: Routledge/Thoemmes.

Rada Legislacyjna przy Kancelarii Prezesa Rady Ministrów (2008). Krajowe przepisy urbanistycz$n e w$ zakresie zasad zabudowy i zagospodarowania terenu uwzględniające przeznaczenie terenu oraz wielkość jednostki osiedleń. Załącznik do ustawy o planowaniu i zagospodarowaniu przestrzennym (projekt). Warszawa.

Shearmur, R. (2010). Scale, distance and embeddedness: Knowledge-intensive business services location and growth in Canada. W: D. Doloreux, M. Freel, R. Shearmur (red.) Knowledge-Intensive Business Services: Geography and Innovation. Farnham Surrey, Burlington Vermont: Ashgate.

Staniszkis, M. (2005). Normatyw urbanistyczny. Prawo do dobrej przestrzeni. Urbanista, 7, 12-14. Stowarzyszenie Architektów Polskich, Towarzystwo Urbanistów Polskich, Izba Architektów RP (2011). Polska polityka architektoniczna. Polityka jakości krajobrazu, przestrzeni publicznej, architektury - Polska Rada Architektury, wydanie II poprawione i poszerzone.

Studium uwarunkowań i kierunków zagospodarowania przestrzennego Wrocławia przyjęte uchwałą nr L/1177/18 Rady Miejskiej Wrocławia z dnia 11 stycznia 2018 r. Kierunki zagospodarowania przestrzennego: struktura funkcjonalno-przestrzenna. (2018). Biuro Rozwoju Wrocławia.

Studium uwarunkowań i kierunków zagospodarowania przestrzennego Wrocławia przyjęte uchwałą nr LIV/3249/06 Rady Miejskiej Wrocławia z dnia 6 lipca 2006 r. ze zmianami. Kierunki zagospodarowania przestrzennego: struktura pasmowa Wrocławia (2010). Biuro Rozwoju Wrocławia 2010.

Ustawa z dnia 27 marca 2003 r. o planowaniu i zagospodarowaniu przestrzennym (Dz.U. nr 80 poz. 717 ze zm.).

Wojnarowska, A. (2017). Jakość przestrzeni publicznej centrum miasta. Przykład miast średnich regionu łódzkiego. Łódź: Wydawnictwo Uniwersytetu Łódzkiego.

Wrocław rozmawia. (2019, 11 November). Strona internetowa Wydziału Partycypacji Społecznej Urzędu Miejskiego Wrocławia. https://www.wroclaw.pl/rozmawia/osiedla-kompletne

Zipf, G.K. (1949). Human behavior and the principle of least effort. Camridge MA: Addison-Wesley Press.

Zipser, T. (1983). Zasady planowania przestrzennego. Wrocław: Oficyna Wydawnicza Politechniki Wrocławskiej.

Łukasz Damurski, PhD - urban planner, post-doc researcher and academic teacher at the Faculty of Architecture, Wroclaw University of Science and Technology, Poland (since 2006). His research interests focus on local (neighbourhood) service centres, the relationship between online and offline services, public communication and citizen participation in urban planning. He has conducted numerous research projects funded within grant programmes from the European Commission, Polish Ministry of Science and National Research Centre Poland. Since 2014 he has been a member of the Editorial Review Board in the International Journal of E-Planning Research (IJEPR). His works - papers and books on various aspects of urban planning theory and practice - are characterised by a wide, political and axiological perspective. Currently, he is working on a multi-disciplinary project on conversion and hybridization of services, i.e. the shift of traditional urban services to the internet.

ORCID: https://orcid.org/0000-0002-9384-9075

\section{Address:}

Wroclaw University of Science and Technology

Faculty of Architecture

ul. B. Prusa 53/55, pok. 120d, 50-317 Wrocław, Poland

e-mail: lukasz.damurski@pwr.edu.pl 